\title{
Impact of Powdery Mildew and Leaf Rust on Milling and Baking Quality of Soft Red Winter Wheat
}

Kathryne L. Everts, University of Maryland, Lower Eastern Shore Research and Education Center, 27664 Nanticoke Road, Salisbury 21801-1648; Steven Leath, USDA-ARS, Department of Plant Pathology, North Carolina State University, Raleigh 27695-7616; and Patrick L. Finney, USDA-ARS, Ohio Agriculture Research and Development Center, Wooster 44691

\begin{abstract}
Everts, K. L., Leath, S., and Finney, P. L. 2001. Impact of powdery mildew and leaf rust on milling and baking quality of soft red winter wheat. Plant Dis. 85:423-429.

Changes in milling and baking quality (especially flour yield) of soft red winter wheat can have a large economic impact on flour mills. To determine the relationship between early-season powdery mildew and late-season leaf rust on flour yield, flour protein, alkaline water retention capacity, and kernel texture (softness equivalent), a study was conducted over 2 years at Kinston and Plymouth, NC. Different levels of powdery mildew and leaf rust developed on three winter wheat cultivars that varied in levels of disease resistance, the presence of seed treatment, and the presence and timing of foliar fungicide application. In Kinston and Plymouth in 1989-90, where leaf rust occurred early, the softness equivalent score was lower in wheat grown from seed treated with triadimenol. The following year, when the leaf rust epidemic increased later, foliar fungicide application reduced disease and resulted in lower softness equivalent scores in both Plymouth and Kinston for cv. Saluda and in Kinston for cv. Coker 983. A regression model was developed to describe the relationship between the log of the area under the disease progress curves and adjusted flour yield (AFY). The AFY of Saluda was reduced in the presence of powdery mildew such that $\% \mathrm{AFY}=103.96-0.92(\log \mathrm{AUMPC})$.
\end{abstract}

Additional keywords: Blumeria graminis f. sp. tritici, crop losses, Puccinia triticina

Wheat growers often receive discounts for their wheat when test weight (a weight per volume measure) is reduced below a standard value. Reduced test weight is used to discount grain because it is perceived to be an indication of poor grain quality and potential reduction in flour yield. Many diseases of wheat affect yield by causing shriveled kernels and reduced test weight. Cephalosporium stripe (Hymenula cerealis Ellis \& Everh. = Cephalosporium gramineum Nisikado \& Ikata in Nisikado et al.), scab (Gibberella zeae (Schwein.) Petch), Septoria leaf blotch (Septoria tritici Roberge in Desmaz.), leaf rust (Puccinia triticina Eriks.), and powdery mildew (Blumeria graminis (DC.) E.O. Speer f. sp. tritici Em. Marchal (=Erysiphe graminis DC. f. sp. tritici Em. Marchal)) reduce test weight $(1,2,12-14,18)$. Severity of leaf rust and leaf blotch at soft dough stage explained 39 to $63 \%$ of test weight losses in Arkansas (14). The impact of disease on

Corresponding author: K. L. Everts

E-mail: ke35@umail.umd.edu

Accepted for publication 22 December 2000.

Publication no. D-2001-0209-02R

This article is in the public domain and not copyrightable. It may be freely reprinted with customary crediting of the source. The American Phytopathological Society, 2001. test weight is more frequently measured than the impact of disease on other quality factors. However, soft wheat, which is used mainly in the production of cookies, crackers, and cakes, has distinct quality specifications (7), and test weight is not always a good predictor of flour yield or milling and baking quality $(10,16)$.

Quality characteristics that are desirable in soft wheat are high test weight $(\geq 0.74$ $\mathrm{kg} / \mathrm{liter}$ ) and uniform kernel size. The wheat should be easy to mill, generally have protein content in the range of 8 to $10 \%$ (14\% moisture basis), and have grain moisture content that does not exceed $15 \%$.

The alkaline water retention capacity (AWRC) microtest measures the quantity of sodium bicarbonate solution absorbed by flour after centrifugation and gives an indication of the suitability of flour for products such as cookies, crackers, cakes, and piecrusts. The percent AWRC correlates inversely with cookie spread and softness equivalent. Generally acceptable AWRC levels are below 56\% (ranging from 47 to $58 \%$ ).

Softness is an estimate of the break flour yield (the flour produced using corrugated rolls in the front end of the mill). Softer textured wheat produces more break flour, which is considered desirable for cracker, cookie, and cake production. Generally, acceptable soft wheat has kernel softness equivalent (SE) values above $50 \%$. Shriveling of grain invariably reduces flour yield but generally increases grain softness and results in elevated SE values. Thus, diseases that cause kernel shriveling may significantly reduce flour yield, but not SE.

Diseases of wheat have had varied impact on flour protein levels. In some studies, leaf rust and powdery mildew reduced wheat flour protein content $(3,4,11,15)$. However, in other locations where powdery mildew, leaf rust, and Septoria leaf blotch were present, a reduction in grain protein levels was not observed $(13,15)$. In a study of the effect of powdery mildew on quality using near-isogenic lines of Chancellor wheat, which differed in at least seven independent genes for resistance to powdery mildew, the total yield and the percent flour protein decreased as the percentage of powdery mildew on the whole plant and the flag leaf increased (11). However, in another study, Soilborne wheat mosaic virus (SBWMV) and Wheat streak mosaic virus (WSMV) infection resulted in increased flour protein content (8).

Wheat test weight, milling flour yield, and alkaline water retention capacity (AWRC) were adversely affected by Septoria leaf blotch (13). Alkaline water retention capacity (AWRC) increased as leaf blotch severity increased. Cephalosporium stripe infection of winter wheat reduced flour yield and water absorption capacity, which is closely related to AWRC (12). SBWMV and WSMV infection in wheat resulted in reduced flour yield (8).

While much research has focused on the effect of wheat diseases on test weight, less information exists on how powdery mildew and leaf rust affect other quality parameters of soft wheat, and some of that information is conflicting. This research was conducted as part of a study on the effect of seed treatment on onset and extent of powdery mildew and leaf rust, and on the effect of subsequent timing of lateseason foliar fungicide applications. The effects of seed treatment and foliar fungicide application on powdery mildew and leaf rust and on maximization of yield have been previously published (6). Here we report the effect of disease epidemics and control of disease by seed treatment and fungicides on various soft wheat milling and baking qualitative traits, including adjusted flour yield, protein, alkaline water retention capacity, and kernel texture, i.e., softness equivalent (SE). 


\section{MATERIALS AND METHODS}

Plot establishment. Similar experiments were conducted during the 1989-90 and 1990-91 growing seasons at the Tidewater Research Station near Plymouth, NC, and at the Lower Coastal Plain Research Station-Cunningham Farm near Kinston, NC. The factorial treatment designs were arranged in randomized complete blocks with three and five replications in the 1989-90 and 199091 seasons, respectively. The three factors were seed treatment (two levels), foliar fungicide application (six levels), and host resistance (three levels). Quality analyses were conducted on all 36 treatments in the 1989-90 growing season. In 1990-91, quality analyses were conducted on 12 treatments: all cultivar and seed treatment combinations but only two levels of foliar fungicide application (no fungicide or fungicide applied at two growth stages).

Table 1. Growth stages (Feekes scale) of winter wheat at time of fungicide applications at Kinston and Plymouth, NC, during 1989-90 and 1990-91

\begin{tabular}{lcccccc}
\hline Location & Season & Early & Mid-early & Mid-late & Late & Early + late \\
\hline Kinston & $1989-1990$ & 8.0 & 10.1 & 10.5 & 11.0 & 8.0 and 11.0 \\
& $1990-1991$ & & & & & 7.0 and 10.52 \\
Plymouth & $1989-1990$ & 8.0 & 9.0 & 10.2 & 10.53 & $\begin{array}{l}6.0 \text { and } 10.53 \\
\end{array}$ \\
\hline
\end{tabular}

Wheat was planted with a small-plot grain drill. Plots were $3.35 \times 2.4 \mathrm{~m}$, consisting of 14 rows spaced $0.24 \mathrm{~m}$ apart. Plots were bordered on two sides with 1.67-m-wide plots of barley (Hordeum vulgare L. cv. Anson) and with $1.2-\mathrm{m}$ alleys on each end to reduce interplot interference. Wheat was planted at Kinston on 17 and 31 October 1989 and 1990, respectively, and at Plymouth on 2 and 5 November 1989 and 1990, respectively. Preplant fertilizer was applied as described previously (6).

Three wheat cultivars grown widely in North Carolina, and which differed in their susceptibility to prevalent races of $B$. graminis f. sp. tritici and $P$. triticina, were planted. Coker 983 (NSG 187415) was moderately resistant to powdery mildew and moderately susceptible to leaf rust; Florida 302 (Cltr 17855) was moderately resistant to both powdery mildew and leaf rust; and Saluda (PI 480474) was suscepti-
Table 2. Powdery mildew and leaf rust severity of three winter wheat cultivars grown with and without triadimenol seed treatment at two locations in North Carolina in 1989-90 and 1990-91

\begin{tabular}{|c|c|c|c|c|c|c|c|c|c|c|c|c|c|c|}
\hline \multirow[b]{3}{*}{$\begin{array}{l}\text { Location, } \\
\text { year, date }\end{array}$} & \multicolumn{6}{|c|}{ Powdery mildew $(\%)^{\mathrm{a}}$} & \multirow[b]{3}{*}{$\mathbf{S E}^{\mathbf{b}}$} & \multicolumn{6}{|c|}{ Leaf rust $(\%)^{\mathrm{a}}$} & \multirow[b]{3}{*}{ SE } \\
\hline & \multicolumn{2}{|c|}{ Saluda } & \multicolumn{2}{|c|}{ Coker 983} & \multicolumn{2}{|c|}{ Florida 302} & & \multicolumn{2}{|c|}{ Saluda } & \multicolumn{2}{|c|}{ Coker 983} & \multicolumn{2}{|c|}{ Florida 302} & \\
\hline & None & $\begin{array}{l}\text { Triadi- } \\
\text { menol }\end{array}$ & None & $\begin{array}{l}\text { Triadi- } \\
\text { menol }\end{array}$ & None & $\begin{array}{l}\text { Triadi- } \\
\text { menol }\end{array}$ & & None & $\begin{array}{l}\text { Triadi- } \\
\text { menol }\end{array}$ & None & $\begin{array}{l}\text { Triadi- } \\
\text { menol }\end{array}$ & None & $\begin{array}{l}\text { Triadi- } \\
\text { menol }\end{array}$ & \\
\hline \multicolumn{15}{|l|}{ Kinston } \\
\hline $27 \mathrm{Feb}$ & 0.009 & 0.000 & 0.000 & 0.000 & 0.001 & 0.000 & 0.001 & $\ldots{ }^{\mathrm{c}}$ & . & . & . & & . & $\ldots$ \\
\hline $28 \mathrm{Mar}$ & 6.61 & 1.66 & 0.25 & 0.04 & 3.67 & 1.64 & 0.50 & 0.27 & 0.15 & 0.29 & 0.08 & 0.01 & 0.00 & 0.09 \\
\hline $11 \mathrm{Apr}$ & 12.74 & 4.93 & 0.10 & 0.22 & 6.08 & 3.52 & 0.72 & 7.09 & 6.85 & 6.26 & 3.36 & 1.55 & 0.40 & 1.70 \\
\hline 2 May & $\ldots^{\mathrm{d}}$ & $\ldots$ & $\ldots$ & $\ldots$ & $\ldots$ & $\ldots$ & $\ldots$ & 11.44 & 12.94 & 17.76 & 17.38 & 4.34 & 2.66 & 1.50 \\
\hline \multicolumn{15}{|l|}{ Plymouth } \\
\hline 1990 & & & & & & & & & & & & & & \\
\hline $22 \mathrm{Mar}$ & $1.38 \times 10^{-3}$ & $1.2 \times 10^{-4}$ & 0.000 & 0.000 & 0.000 & 0.000 & $1.19 \times 10^{-2}$ & $\ldots{ }^{\mathrm{c}}$ & & $\ldots$ & $\ldots$ & & & \\
\hline $5 \mathrm{Apr}$ & 0.060 & 0.00 & 0.00 & 0.00 & 0.00 & 0.00 & 0.012 & 0.32 & 0.51 & 0.48 & 0.53 & 0.29 & 0.20 & 0.098 \\
\hline $20 \mathrm{Apr}$ & 1.13 & 0.31 & 0.00 & 0.00 & 0.02 & 0.00 & 0.13 & 4.64 & 6.46 & 8.17 & 6.63 & 2.45 & 1.92 & 0.99 \\
\hline 8 May & $\ldots{ }^{\mathrm{d}}$ & $\ldots$ & $\ldots$ & $\ldots$ & $\ldots$ & $\ldots$ & $\ldots$ & 38.20 & 28.78 & 39.8 & 37.44 & 18.88 & 19.48 & 3.14 \\
\hline \multicolumn{15}{|l|}{ Kinston } \\
\hline \multicolumn{15}{|l|}{1991} \\
\hline $6 \mathrm{Feb}$ & 5.60 & 0.00 & 0.00 & 0.00 & 1.85 & 0.00 & 1.07 & $\ldots{ }^{c}$ & & & & & & \\
\hline $9 \mathrm{Apr}$ & 0.80 & 0.47 & 0.23 & 0.00 & 0.98 & 0.00 & 0.13 & 0.02 & 0.02 & 0.00 & 0.14 & 0.30 & 0.20 & 0.66 \\
\hline $26 \mathrm{Apr}$ & 12.02 & 4.69 & 0.34 & 0.00 & 3.61 & 0.86 & 0.89 & 2.46 & 3.63 & 3.26 & 4.22 & 3.12 & 1.56 & 0.99 \\
\hline 8 May & $\ldots{ }^{d}$ & $\ldots$ & $\ldots$ & $\ldots$ & $\ldots$ & $\ldots$ & $\ldots$ & 13.84 & 15.36 & 28.20 & 25.28 & 15.61 & 12.32 & 3.00 \\
\hline \multirow{2}{*}{\multicolumn{15}{|c|}{ Plymouth }} \\
\hline & & & & & & & & & & & & & & \\
\hline $13 \mathrm{Feb}$ & 0.16 & 0.00 & 0.00 & 0.00 & 0.00 & 0.00 & 0.04 & $\ldots^{\mathrm{c}}$ & $\ldots$ & $\ldots$ & $\ldots$ & $\ldots$ & $\ldots$ & $\ldots$ \\
\hline $17 \mathrm{Apr}$ & 1.60 & 2.04 & 0.34 & 0.26 & 2.12 & 1.86 & 0.45 & 0.06 & 0.04 & 0.02 & 0.00 & 0.02 & 0.08 & 0.03 \\
\hline 2 May & 4.44 & 2.76 & 0.14 & 0.10 & 2.07 & 0.84 & 0.62 & 3.39 & 3.52 & 5.85 & 3.72 & 1.13 & 2.36 & 0.79 \\
\hline 9 May & $\ldots{ }^{\mathrm{d}}$ & $\ldots$ & $\ldots$ & $\ldots$ & $\ldots$ & $\ldots$ & $\ldots$ & 24.88 & 24.72 & 25.36 & 18.32 & 8.52 & 9.48 & 5.54 \\
\hline
\end{tabular}

${ }^{a}$ Powdery mildew severity was assessed on whole plots for the first date each year in each location by estimating the number of plants infected and by estimating the approximate percentage of infected leaf area on each plant in $0.5 \mathrm{~m}$ of row in two to three locations within each plot. Subsequent assessments were made estimating powdery mildew and leaf rust severity as the percentage of leaf tissue covered with pustules on the flag and penultimate leaves of 10 randomly selected culms per plot.

${ }^{\mathrm{b}} \mathrm{SE}=$ standard error.

${ }^{\mathrm{c}}$ No leaf rust was observed.

${ }^{\mathrm{d}}$ No actively growing powdery mildew colonies were observed. ble to both powdery mildew and leaf rust $(1,5,6)$.

Fungicide application. Seed for onehalf of the plots was treated with triadimenol (Baytan 30F, Gustafson, Plano, TX) at $0.26 \mathrm{~g}$ a.i. $/ \mathrm{kg}$ of seed. The remaining seed was not treated. Foliar fungicides triadimefon (Bayleton 50 DF, Bayer Chemical Co., Kansas City, MO) and mancozeb (Manzate 200 DF, E.I. DuPont de Nemours \& Co., Wilmington, DE) were applied during $1989-90$ and $1990-91$ at $68.0 \mathrm{~g}$ a.i./ha and $1.64 \mathrm{~kg}$ a.i./ha, respectively. Fungicides were applied with a $\mathrm{CO}_{2}$-pressurized backpack sprayer delivering 234 liters/ha at 240 $\mathrm{kPa}$. The timings of foliar fungicide applications at both locations during both seasons were based on growth stage (Feekes scale) (Table 1).

Disease assessment. Incidence and severity of both powdery mildew and leaf rust were assessed on whole plots before the emergence of the flag leaf. Assessments were made on 8 and 27 February at Kinston and on 9 and 28 February and 22 March at Plymouth during 1990. Assessments were made by estimating the percentage of plants infected and by estimating the approximate percentage of leaf area infected on each plant in $0.5 \mathrm{~m}$ of row in two or three locations within each plot. After flag leaf emergence, leaf rust severity 
as the percentage of leaf tissue covered with pustules (a modified Cobb scale) was assessed weekly on the flag and penultimate leaves of 10 randomly selected culms per plot (on 21 and 28 March, 4, 11, 18, and 25 April, and 2 May at Kinston and on 5, 12, 20, and 26 April and 8 May at Plymouth) during 1990. Powdery mildew severity was assessed on the same 10 culms by estimating the percentage of leaf area covered with pustules (on 21 March and 13 and 25 April at Kinston and on 5 and 20 April and 8 May at Plymouth). During 1991, whole-plot assessments of powdery mildew and leaf rust were made on 6 February and 20 March at Kinston and on 13 February and 6 and 21 March at Plymouth. Assessments on the flag and penultimate leaves of 10 randomly selected culms per plot were made on 4, 9, 16, and 26 April and 8 May at Kinston and on 5, 12, and 17 April and 2 and 9 May at Plymouth.

Quality assessment. Grain was harvested from a $1.7 \times 2.4 \mathrm{~m}$ area of the plot, and a 500-g sample was shipped to the USDA-ARS Soft Wheat Quality Laboratory at Wooster, OH. Adjusted flour yield was determined as percent flour yield of grain regressed by grain texture and grain moisture (to equalize the milling condition) (9). SE was determined as described by Finney and Andrews (9). Kjeldahl nitrogen was determined on flours according to Method 46-12 (AACC, 1983), and AWRC was determined on flours as described by Yamazaki (19). Protein concentration (g $\mathrm{kg}^{-1}$ ) was calculated on a $14 \%$ moisture basis as $\mathrm{N}$ concentration $\left(\mathrm{g} \mathrm{kg}^{-1}\right) \times 5.7$. Dockage (such as straw) was removed using the Carter-Day Dockage Remover (Carter-Day Co., Minneapolis, MN). Evaluations were conducted on each sample without removing shriveled seed.

Data analyses. There were highly significant treatment by location interactions when data were analyzed across years and locations because of the variation in onset and severity of powdery mildew and leaf rust (Table 2) (6). Therefore, subsequent analysis was conducted for individual locations and years. To determine treatment effects, analyses of variance were performed on adjusted flour yield, percent protein, alkaline water retention capacity, and SE. Areas under the powdery mildew progress curve (AUMPC) and areas under the leaf rust progress curves (AURPC) were calculated from disease assessment data (17). The $\log$ of the AUMPC and AURPC was calculated for each plot. (Some plots had areas under the curve of zero, so one was added to all areas prior to calculating the log.) Pearson's correlation coefficients were calculated for the $\log$ of the areas under the disease progress curves and the quality measurements. When correlations between disease and quality measurements were greater than 0.40 , they were used to develop quality loss models by regressing log AUMPC or log AURPC values on quality measurements. When a correlation coefficient between an area under the disease progress curve and quality parameter was greater than $0.40(P \leq$ 0.05 ) in more than one environment, the data were combined across all environments to develop a single quality loss model. Loss models were considered acceptable for describing the relationship between disease and quality when $R^{2}$ was 0.40 or greater and $P \leq 0.01$. A loss model was developed to describe the relationship between the percent maximum adjusted flour yield of Saluda and the log AUMPC. The maximum adjusted flour yield was calculated as the average adjusted flour yield from plots where seed had been treated with triadimenol and where plots had received two fungicide applications.

Table 3. Analysis of variance of percent adjusted flour yield, percent protein, alkaline water retention capacity (AWRC), and softness equivalent of three winter wheat cultivars grown with and without triadimenol seed treatment and with foliar fungicides applied at varied growth stages at two locations in North Carolina in 1989-90

\begin{tabular}{|c|c|c|c|c|c|}
\hline \multirow[b]{2}{*}{ Factor } & \multicolumn{5}{|c|}{ Mean square } \\
\hline & df & $\begin{array}{l}\text { \% Adjusted } \\
\text { flour yield }\end{array}$ & $\%$ Protein & AWRC & $\begin{array}{c}\text { Softness } \\
\text { equivalent }\end{array}$ \\
\hline \multicolumn{6}{|l|}{ Kinston } \\
\hline Replicate & 2 & $1.7 * * a$ & $0.9 * *$ & 0.1 & $11.6^{* * *}$ \\
\hline Cultivar (C) & 2 & $32.4 * *$ & $1.7 * *$ & $25.3 * *$ & $157.2 * *$ \\
\hline Seed treatment (ST) & 1 & 0.4 & $0.4^{*}$ & 0.0 & $11.0 * *$ \\
\hline $\mathrm{C} \times \mathrm{ST}$ & 2 & $2.0 * *$ & $0.4 * *$ & $1.0+$ & $9.6^{* * *}$ \\
\hline Fungicide (F) & 5 & $1.1 * *$ & $0.2 *$ & 0.1 & $13.5 * *$ \\
\hline $\mathrm{C} \times \mathrm{F}$ & 10 & 0.3 & 0.0 & 0.5 & $2.6+$ \\
\hline $\mathrm{ST} \times \mathrm{F}$ & 5 & 0.1 & 0.1 & 0.7 & $3.1+$ \\
\hline $\mathrm{C} \times \mathrm{ST} \times \mathrm{F}$ & 10 & 0.4 & 0.1 & 0.2 & 0.5 \\
\hline Error & 70 & 0.2 & 0.1 & 0.4 & 1.5 \\
\hline \multicolumn{6}{|l|}{ Plymouth } \\
\hline Replicate & 2 & $0.4^{\mathrm{b}}$ & $0.7^{b}$ & 0.4 & 1.3 \\
\hline Cultivar (C) & 2 & 7.1 & 0.1 & $76.9 * *$ & $12.7 * *$ \\
\hline Seed treatment (ST) & 1 & 1.3 & 0.1 & 0.6 & $6.6^{*}$ \\
\hline $\mathrm{C} \times \mathrm{ST}$ & 2 & 0.2 & 0.2 & 0.5 & 3.5 \\
\hline Fungicide (F) & 5 & 0.3 & 0.3 & 0.5 & $10.3 * *$ \\
\hline $\mathrm{C} \times \mathrm{F}$ & 10 & 0.4 & 0.3 & 0.6 & $2.9+$ \\
\hline $\mathrm{ST} \times \mathrm{F}$ & 5 & 0.7 & 0.1 & 0.5 & 1.2 \\
\hline $\mathrm{C} \times \mathrm{ST} \times \mathrm{F}$ & 10 & 0.6 & 0.1 & 0.3 & 1.4 \\
\hline Error & 70 & 0.6 & 0.2 & 0.7 & 1.6 \\
\hline
\end{tabular}

${ }^{\mathrm{a}}+{ }^{*}$, and $* *$ represent significant treatment effects at the $P=0.10, P=0.05$, and $P=0.01$ level of probability, respectively.

b The overall $F$ test for the model was not $<0.05$.

Table 4. Analysis of variance percent adjusted flour yield, percent protein, alkaline water retention capacity (AWRC), and softness equivalent of three winter wheat cultivars grown with and without triadimenol seed treatment, and with or without foliar fungicide application at two locations in North Carolina in 1990-91

\begin{tabular}{|c|c|c|c|c|c|}
\hline \multirow[b]{2}{*}{ Factor } & \multicolumn{5}{|c|}{ Mean square } \\
\hline & df & $\begin{array}{l}\% \text { Adjusted } \\
\text { flour yield }\end{array}$ & $\%$ Protein & AWRC & $\begin{array}{c}\text { Softness } \\
\text { equivalent }\end{array}$ \\
\hline \multicolumn{6}{|l|}{ Kinston } \\
\hline Replicate & 4 & $0.3 * \mathrm{a}$ & $0.2+$ & $1.1 * *$ & $3.2 *$ \\
\hline Cultivar (C) & 2 & $18.1^{* *}$ & $1.1 * *$ & $39.2 * *$ & $7.8 * *$ \\
\hline Seed treatment (ST) & 1 & 0.2 & 0.2 & 0.1 & 0.4 \\
\hline $\mathrm{C} \times \mathrm{ST}$ & 2 & 0.1 & 0.0 & 0.0 & 0.1 \\
\hline Fungicide (F) & 1 & 0.0 & 0.2 & 0.1 & $34.3^{* *}$ \\
\hline $\mathrm{C} \times \mathrm{F}$ & 2 & 0.1 & $0.3+$ & $0.5+$ & $7.5^{* *}$ \\
\hline $\mathrm{ST} \times \mathrm{F}$ & 1 & 0.0 & 0.1 & 0.1 & 0.0 \\
\hline $\mathrm{C} \times \mathrm{ST} \times \mathrm{F}$ & 2 & $0.5^{*}$ & 0.0 & 0.4 & 0.4 \\
\hline Error & 42 & 0.1 & 0.1 & 0.2 & 0.9 \\
\hline \multicolumn{6}{|l|}{ Plymouth } \\
\hline Replicate & 4 & 0.1 & 0.1 & 0.2 & 1.0 \\
\hline Cultivar (C) & 2 & $8.8 * *$ & $4.1 * *$ & $11.0 * *$ & $108.7 * *$ \\
\hline Seed treatment (ST) & 1 & 0.0 & $0.7+$ & 0.0 & 1.1 \\
\hline $\mathrm{C} \times \mathrm{ST}$ & 2 & $0.4 * *$ & 0.3 & 0.1 & 0.4 \\
\hline Fungicide (F) & 1 & 0.0 & 0.2 & 0.0 & $5.8 *$ \\
\hline $\mathrm{C} \times \mathrm{F}$ & 2 & 0.1 & $0.6+$ & 0.3 & $6.8 * *$ \\
\hline $\mathrm{ST} \times \mathrm{F}$ & 1 & 0.0 & 0.0 & 0.0 & 1.0 \\
\hline $\mathrm{C} \times \mathrm{ST} \times \mathrm{F}$ & 2 & 0.0 & 0.2 & $0.8 *$ & 1.6 \\
\hline Error & 44 & 0.1 & 0.2 & 0.2 & 1.0 \\
\hline
\end{tabular}

${ }^{\mathrm{a}}+{ }^{*}$, and $* *$ represent significant treatment effects at the $P=0.10, P=0.05$, and $P=0.01$ level of probability, respectively. 

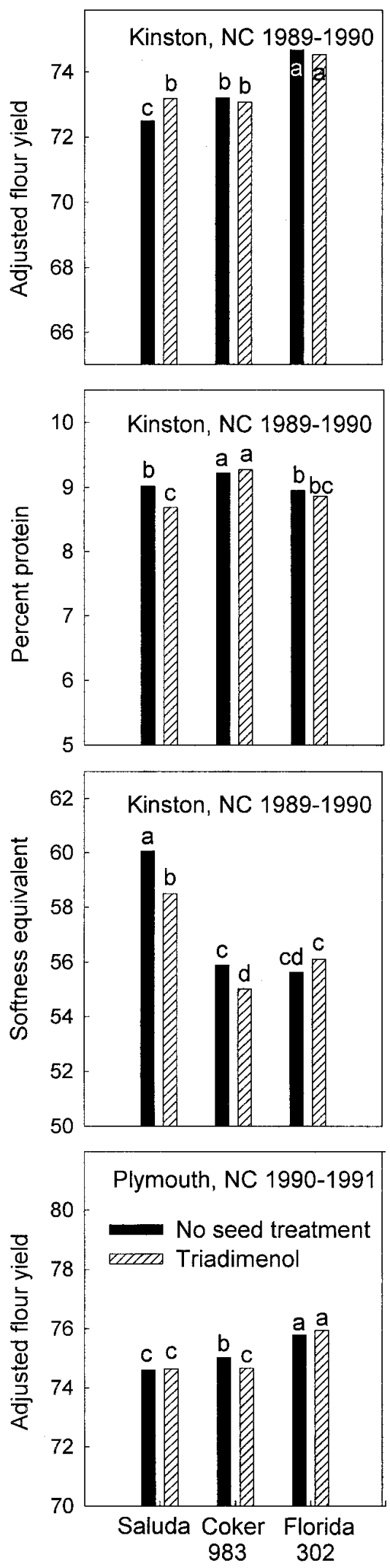

Fig. 1. Soft wheat qualitative traits of three cultivars of winter wheat grown at Kinston, NC, 1989-90, or Plymouth, 1990-91, from seed treated with triadimenol or nontreated seed. Means are averaged over all foliar fungicide applications (bars with the same letter are not significantly different according to Fisher's protected LSD, $P=0.05$ ).
The percent maximum adjusted flour yield for a plot was the plot-adjusted flour yield divided by the maximum adjusted flour yield multiplied by 100 .

\section{RESULTS}

Disease severity. Powdery mildew was more severe at Kinston than at Plymouth both seasons where onset occurred in January (1990) or February (1991) and declined by the beginning of May (Table 2). In Plymouth, mildew increased in April and declined in May of both years (Table 2). Leaf rust epidemics occurred in April in all environments and increased until harvest. Leaf rust was most severe in Plymouth in 1989-90 (Table 2).
Adjusted flour yield. In Kinston (198990) and Plymouth (1990-91), the effect of seed treatment on adjusted flour yield depended on the cultivar (Tables 3 and 4). Adjusted flour yield was greater in cultivar Saluda, which had been treated with triadimenol to control mildew, than in wheat grown from nontreated seed at Kinston in 1989-90 (Fig. 1). Neither Coker 983 nor Florida 302, both of which were more resistant to mildew, showed that response (Fig. 1). However, at Plymouth (1990-91 season), Coker 983 wheat had lower adjusted flour yield when seed had been treated with triadimenol (Fig. 1). Two fungicide applications resulted in increased adjusted flour yield at Kinston in 1989-90
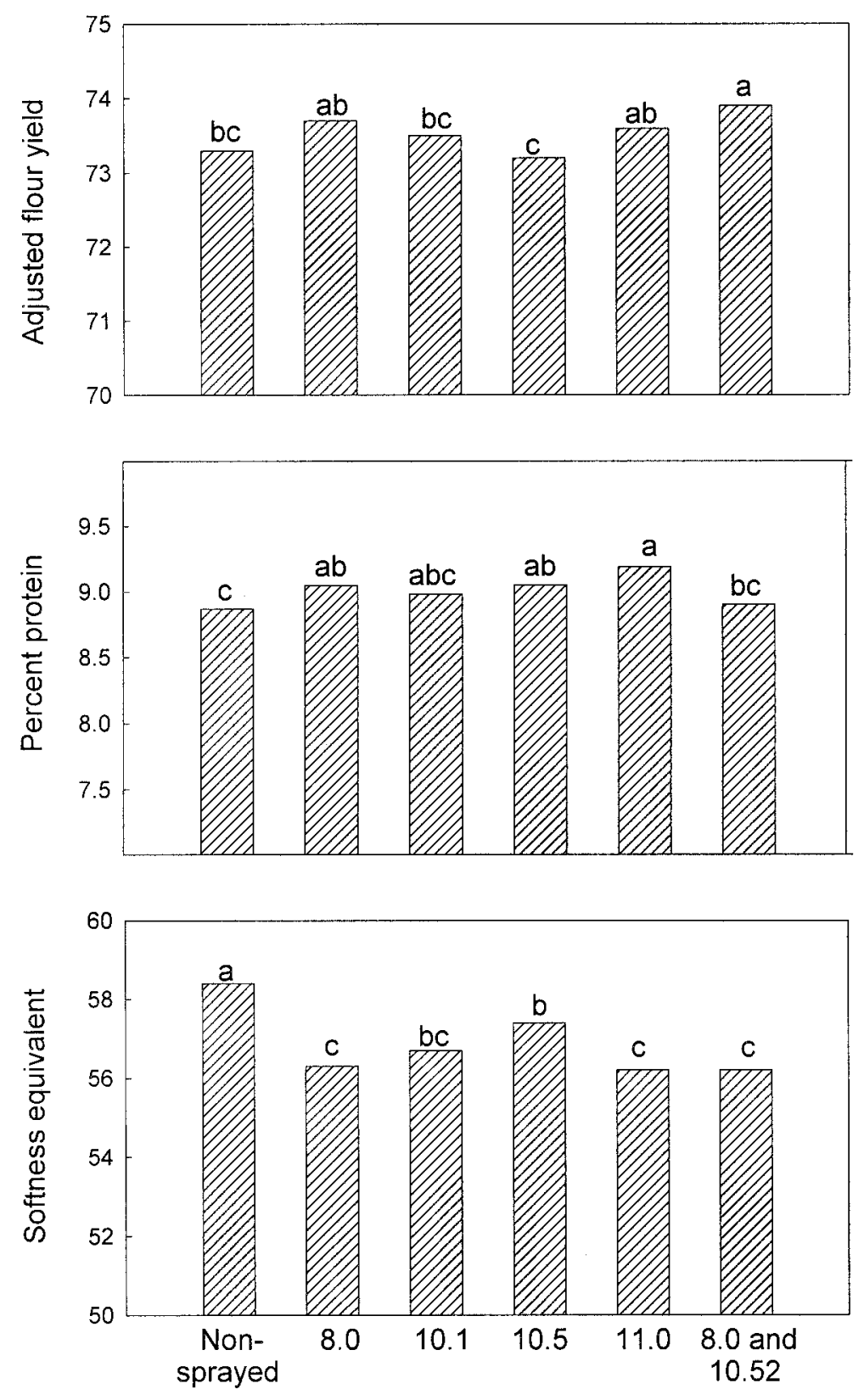

Growth stage (Feekes scale) of fungicide application

Fig. 2. Soft wheat qualitative traits of winter wheat grown at Kinston, NC, 1989-90, resulting from varied foliar fungicide application times, averaged over cultivars and seed treatments (bars with the same letter are not significantly different according to Fisher's protected LSD, $P=0.05$ ). 
when compared with plots sprayed at growth stage 10.1, 10.5, or not at all (Fig. 2).

Protein. The impact of disease control on percent protein varied by cultivar and environment (Tables 3 and 4). At Kinston (1989-90), percent protein in Saluda grown from seed treated with triadimenol decreased from 9.02 to 8.69 (Fig. 1). However, in the same year and location, fungicides applied at growth stages 8.0, 10.5, and 11.0 resulted in higher percent proteins when averaged over all cultivars compared with wheat that was not sprayed (Fig. 2). Neither change resulted in a protein content outside the desired range for soft red winter wheat ( 8 to $10 \%$ at $14 \%$ moisture).

Alkaline water retention capacity. In Florida 302 at Plymouth 1990-91, both seed treatment and fungicide applications resulted in lower AWRC (55.50 and 55.54, respectively) compared with nontreated plots (56.00). However, AWRC was increased in Saluda grown from nontreated seed that received two foliar fungicide applications compared with unsprayed and nontreated Saluda (57.36 and 56.62, respectively). In Coker 983, no differences in AWRC resulted from any treatment.

Kernel softness. Kernel softness was the quality parameter that was most often and consistently affected by seed treatment and fungicide (Tables 3 and 4). Saluda and Coker 983 wheat grown from seed treated with triadimenol at Kinston 1989-90 had lower SE (i.e., grain was harder or more coarse) than nontreated wheat (Fig. 1). The mean SE of all cultivars was reduced in wheat grown from treated seed compared with nontreated seed at Plymouth in 198990, 51.7 and 52.2, respectively. Fungicide application in all cultivars resulted in reduced mean SE at both Kinston and Plymouth in 1989-90 compared with wheat that did not receive fungicide applications (Figs. 2 and 3). At Kinston, applications at growth stage $8.0,10.1,10.5,11.0$, or at both 8.0 and 11 resulted in a reduced SE. At Plymouth, a single fungicide application at growth stage 10.2 resulted in a reduced SE. When wheat received two applications (growth stage 6.0 and 10.53), the SE was lower than unsprayed wheat and wheat that received only one fungicide application (Fig. 3). At Kinston and Plymouth the following year, SE was reduced when Saluda wheat received two fungicide applications (GS 7.0 and 10.52) compared with no fungicides (Fig. 4). Likewise, Coker 983 had lower SE at Kinston when two fungicide sprays were applied (Fig. 4).

Loss models. In Kinston 1989-90 and Plymouth 1990-91, the percent maximum adjusted flour yield of Saluda was negatively related to powdery mildew severity, and a loss model was developed (Fig. 5).

Some quality factors were correlated with disease in more than one environment, but the loss model developed from the data combined over years did not have an $R^{2}$ of 0.40 or greater. Adjusted flour yield was negatively correlated with $\log$ AURPC on Saluda wheat in Kinston in 1989-90 $\left(P_{r}>R=0.0037\right)$ and in Plymouth in 1990-91 $\left(P_{r}>R=0.0362\right)$.

Some correlations were significant in only one location and therefore not used in developing a quality loss model. Flour protein and softness were positively correlated to $\log$ AUMPC on Saluda wheat in Kinston in 1989-90 $\left(P_{r}>R=0.0004\right.$; and $P_{r}>R=0.0002$, respectively). However, protein was negatively correlated with $\log$ AURPC on Coker 983 wheat $\left(P_{r}>R=\right.$ 0.0210 ) at Plymouth in 1990-91.

\section{DISCUSSION}

Wheat is purchased based on several factors. The class (spring or winter, soft or hard, and red or white) is the most important factor. Within each class, grade is determined by the percent shrunken, broken, or diseased kernels. Test weight, calculated on the weight-volume ratio, de- termines whether the growers receive a discount price. However, test weight is not always closely related to the quality factors that are important to the processors $(10,16)$. Specifically, test weight is a poor predictor of flour yield, and here we observed no impact of fungicide on percent

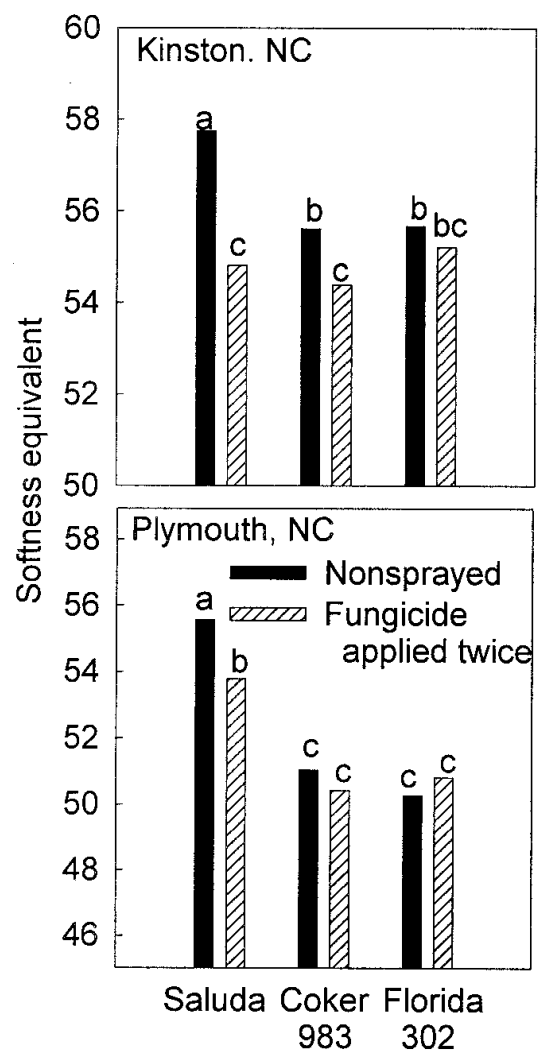

Fig. 4. Softness equivalent score of three cultivars of winter wheat grown at Kinston or Plymouth, NC, 1990-91, that were sprayed with a foliar fungicide application at GS 7.0 and 10.52 or nonsprayed. Means were averaged over seed treatments (columns with the same letter are not significantly different according to Fisher's protected $\mathrm{LSD}, P=0.05)$.

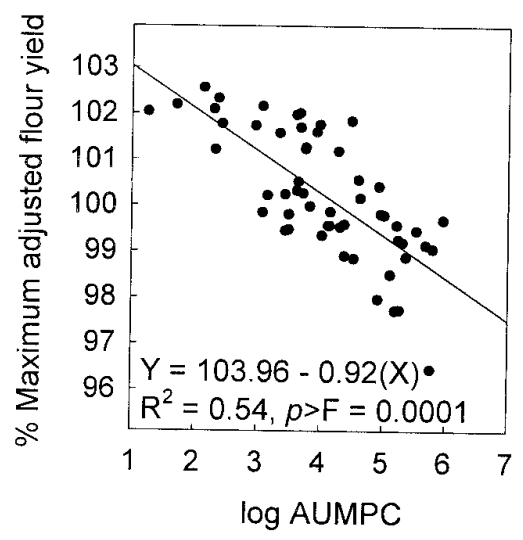

Fig. 5. Relationship between percent maximum adjusted flour yield and the log of the area under the powdery mildew progress curve (log AUMPC) on winter wheat (cultivar Saluda) grown at Kinston and Plymouth, NC, during 1989-90 and 1990-91, respectively.
Fig. 3. Softness equivalent score of winter wheat grown at Plymouth, NC, 1989-90, resulting from varied foliar fungicide application times, averaged over cultivars and seed treatments (bars with the same letter are not significantly different according to Fisher's protected LSD, $P=0.05$ ). 
adjusted flour yield at Kinston or Plymouth in 1990-91. Yet an increase in kernel weight occurred in both environments in response to fungicide applications (Table 5). Conversely, a reduction in flour yield can have a large economic impact on a mill (16). A decrease in adjusted flour yield of 0.6 percentage point could represent a yearly loss of $\$ 300,000$ to a mill producing 454 thousand kilograms (1 million pounds) of flour per day (10). This was the level of reduction in flour yield we observed at Kinston (1989-90) when plots were unsprayed compared with receiving two fungicide applications. That loss was in addition to estimated grain yield loss at this location in unsprayed plots compared with sprayed plots of $689,1,079$, and 1,107 $\mathrm{kg} / \mathrm{ha}$ on Saluda, Coker 983, and Florida 302 , respectively (6). Yet at this location there was no significant difference in 500 kernel weight due to fungicide application (Table 5).

Schuler et al. (16) observed that because flour yield is a complex trait and the sum of many minor effects, it is difficult to predict. Milling flour yield is based on soundness (freedom of weathering), kernel fullness (freedom of shriveling), and genetically controlled flour yield potential (10). Diseases affect degree of soundness and kernel fullness (i.e., test weight or kernel weight). Diseases that cause shriveling of grain generally increase the ratio of protein to starch. Shriveling, in turn, causes proportionate losses in flour yield. However, the impacts of disease do not always cause protein to increase, and the effect of disease may be greater than shriveling alone. Diseases have caused both increase and decrease in flour protein $(3,8,11)$. Here we found a positive correlation between percent protein and severity of powdery mildew on Saluda at Kinston in 1989-90, and a negative correlation between leaf rust severity and protein on Coker 983 at Plymouth in 1990-91. The impact of an increase or decrease in protein level depends on the end use of the flour because individual buyers have specific criteria for protein levels. A decrease in the protein level of grain is not inherently bad and may be associated with good product tenderness. Because test weight is positively correlated to protein, Schuler et al. (16) suggested that selection for high test weight might be detrimental to baking quality. In our experiments, disease increased protein levels in some environments and decreased protein in others but did not result in protein levels outside the range of acceptable quality.

Here we have shown that where disease was severe, even a single fungicide application improved some quality parameters. Flour yield was consistently improved as disease severity was reduced in response to seed treatment or fungicide application. At the same time we observed a decrease in SE associated with disease reduction, indicating disease reduction was associated with harder or coarser flour. However, SE score was never reduced enough to be below the acceptable range (50 to 60) for soft wheat. The optimum growth stage for fungicide application to maximize yield in Plymouth during the 1989-90 growing season was Feekes GS 10.2 (6). Fungicide applied at this growth stage reduced the SE score more than any other treatment. Yield data from this environment demonstrated that both susceptible and moderately resistant wheat grown from triadimenol-treated seed had higher yields. Flour yield was also improved when susceptible and moderately resistant wheat was grown from treated seed. Thus, the economic benefit in controlling disease will be realized by processors as well as producers.

Table 5. Mean 500 kernel weight (g) of three cultivars of winter wheat treated with or without foliar fungicide applications ${ }^{\mathrm{a}}$ at Kinston and Plymouth, NC

\begin{tabular}{|c|c|c|c|c|c|}
\hline & \multicolumn{2}{|c|}{ No seed treatment } & \multicolumn{2}{|c|}{ Seed treatment } & \multirow[b]{2}{*}{$\begin{array}{c}\text { Standard } \\
\text { error }\end{array}$} \\
\hline & $\begin{array}{l}\text { No foliar } \\
\text { fungicide }\end{array}$ & Fungicide & $\begin{array}{l}\text { No foliar } \\
\text { fungicide }\end{array}$ & Fungicide & \\
\hline \multicolumn{6}{|c|}{ Kinston 1989-90 } \\
\hline Saluda & 17.4 & 17.9 & 17.4 & 17.1 & 0.78 \\
\hline Coker 983 & 18.2 & 17.3 & 18.4 & 17.2 & 0.61 \\
\hline Florida 302 & 17.8 & 17.0 & 18.8 & 18.2 & 0.64 \\
\hline \multicolumn{6}{|c|}{ Plymouth 1989-90 } \\
\hline Saluda & 17.2 & 18.2 & 17.3 & 18.4 & 0.22 \\
\hline Coker 983 & 15.6 & 16.5 & 15.9 & 16.6 & 0.27 \\
\hline Florida 302 & 18.3 & 20.0 & 18.7 & 19.5 & 0.45 \\
\hline \multicolumn{6}{|c|}{ Kinston 1990-91 } \\
\hline Saluda & 15.0 & 16.0 & 15.3 & 16.1 & 0.21 \\
\hline Coker 983 & 15.6 & 16.2 & 15.2 & 16.3 & 0.29 \\
\hline Florida 302 & 18.1 & 19.9 & 18.8 & 19.9 & 0.30 \\
\hline \multicolumn{6}{|c|}{ Plymouth 1990-91 } \\
\hline Saluda & 15.0 & 16.5 & 15.4 & 16.0 & 0.23 \\
\hline Coker 983 & 16.4 & 16.6 & 15.0 & 15.5 & 0.33 \\
\hline Florida 302 & 17.9 & 18.9 & 18.0 & 19.3 & 0.27 \\
\hline
\end{tabular}

${ }^{a}$ Foliar fungicide treatments consisted of 68.05 and $1.64 \mathrm{~kg}$ a.i./ha of triadimenol and mancozeb, respectively, applied at Feekes GS 6-8 and GS 10.55-11.0.
Quality losses due to disease occurred both before and during grain fill. Leaf rust occurred later in the season than powdery mildew, and it had a relatively greater impact on quality parameters such as SE. Powdery mildew reduced quality even in environments where severity was low (Plymouth 1991). Seed treatment primarily controlled powdery mildew (6), but often resulted in lower SE scores. Reduced flour yield in Coker 983 at Plymouth 1990-91, when seed was treated with triadimenol, may have been a result of high late-season rust pressure that was unaffected by seed treatment. However, this also may have resulted from a more complex interaction between seed treatment and yield traits. Triadimenol can reduce tiller number early in the season. Powdery mildew stimulates tiller production (due to compensation by the plant), but few infected tillers survive until harvest (5). At this location, both high tiller numbers and kernel weight were responsible for high yield. Competition between tillers may have resulted in negative effect on quality. Coker 983 also was the only cultivar at this location that did not yield more when grown from treated seed (6).

In most environments, the quality of susceptible Saluda was impacted to a much greater extent than the moderately resistant line Florida 302. In addition, the quality of Coker 983 was greatly impacted by disease while the quality of Florida 302 was not. Yet these cultivars differed in that Coker 983 was moderately susceptible to leaf rust and Florida 302 was moderately resistant. This indicated that some cultivars may sustain damage due to disease without a corresponding decrease in quality (such as Florida 302), yet others with similar amounts of disease will have reduced quality.

Wheat quality is a complex trait. With improved understanding of the impact of each component of quality to the value added process, a more direct method of quality assessment (as assessment technology improves) may be preferred over test weight assessment. Once grain purchasers begin evaluating specific quality parameters, such as flour yield and SE, the effect of disease on quality will affect disease control decisions by growers.

\section{LITERATURE CITED}

1. Bowen, K. L., Everts, K. L., and Leath, S. 1991. Reduction in yield of winter wheat in North Carolina due to powdery mildew and leaf rust. Phytopathology 81:503-511.

2. Bruckner, P. L., and Finney, P. L. 1992. Milling and baking quality attributes of soft red winter wheat bulk populations and derived lines. Crop Sci. 32:1174-1179.

3. Caldwell, R. M., Kraybill, H. R., Sullivan, J. T., and Compton, L. E. 1934. Effect of leaf rust (Puccinia triticina) on yield, physical characters, and composition of winter wheats. J. Agric. Res. 48:1049-1071.

4. Dyck, P. L., and Lukow, O. M. 1988. The genetic analysis of two interspecific sources 
of leaf rust resistance and their effect on the quality of common wheat. Can. J. Plant. Sci. 68:633-639.

5. Everts, K. L., and Leath, S. 1992. Effect of early season powdery mildew on development, survival, and yield contribution of tillers of winter wheat. Phytopathology 82:12731278.

6. Everts, K. L., and Leath, S. 1993. Effect of triadimenol seed treatment and timing of foliar fungicide applications on onset and extent of powdery mildew and leaf rust epidemics. Phytopathology 83:557-562.

7. Faridi, H., Gaines, C., and Finney, P. 1994. Soft wheat quality in production of cookies and crackers. Pages 154-168 in: Wheat Production, Properties and Quality. W. Bushuk and V. F. Rasper, eds. Blackie Academic and Professional, Glasgow, UK.

8. Finney, K. F., and Sill, W. H., Jr. 1963. Effects of two virus diseases on milling and baking properties of wheat grain and flour and on probable nutritive value of forage wheat. Agron. J. 55:476-478.
9. Finney, P. L., and Andrews, L. C. 1986. Revised microtesting for soft wheat quality evaluation. Cereal Chem. 63:177-182.

10. Finney, P. L., and Bergman, C. 1996. Test weight in relation to various milling and baking properties of eastern U.S. soft wheat.

Proc. Regional Quality Sympos. Soft Red Winter Wheat - September 7-8, 1994. University of Arkansas Press, Fayetteville.

11. Johnson, J. W., Baenzinger, P. S., Yamazaki, W. T., and Smith, R. T. 1979. Effects of powdery mildew on yield and quality of isogenic lines of 'Chancellor' wheat. Crop Sci. 19:349352.

12. Mathre, D. E., Johnston, R. H., and McGuire, C. F. 1977. Cephalosporium stripe of winter wheat: Pathogen virulence, sources of resistance, and effect on grain quality. Phytopathology 67:1142-1148.

13. McKendry, A. L., Henke, G. E., and Finney, P. L. 1995. Effects of Septoria leaf blotch on soft red winter wheat milling and baking quality. Cereal Chem. 72:142-146.

14. Milus, E. A. 1994. Effects of leaf rust and
Septoria leaf blotch on yield and test weight of wheat in Arkansas. Plant Dis. 78:55-59.

15. Morris, C. F., Ferguson, D. L., and Paulsen, G. M. 1989. Nitrogen fertilizer management with foliar fungicide and growth regulator for hard winter wheat production. Appl. Agric. Res. 4:135-140.

16. Schuler, S. F., Bacon, R. K., Finney, P. L., and Gbur, E. E. 1995. Relationship of test weight and kernel properties to milling and baking quality in soft red winter wheat. Crop Sci. 35:949-953.

17. Tooley, P. W., and Grau, G. R. 1984. Field characterization of rate-reducing resistance to Phytophthora megasperma f. sp. glycinea in soybeans. Phytopathology 74:1201-1208.

18. Tuite, J., Shaner, G., and Everson, R. J. 1990. Wheat scab in soft red winter wheat in Indiana in 1986 and its relation to some quality measurements. Plant Dis. 74:959-962.

19. Yamazaki, W. T. 1953. An alkaline water retention capacity test for the evaluation of cookie baking potentialities of soft winter wheat flours. Cereal Chem. 30:242-246. 